\title{
Freeze-dried bamboo shoot powder for food fortification: enrichment of nutritional content and organoleptic qualities of fortified biscuits
}

\begin{abstract}
Background: Bamboo shoots are low-calorie vegetables rich in nutrients and phytochemicals. Due to the presence of antinutrients and short shelf life, the shoots need to be processed for long term usage. Vacuum freeze-drying is the best method of water removal from perishable vegetables compared to other methods of drying. Edible portion of shoots were freeze dried in three forms, fresh, 20minutes boiled and 24 hours soaked and compared with wheat flour. Freeze dried bamboo shoot powder were used for fortification of biscuits. Nutrients, bioactive compounds and minerals were increased in bamboo shoot fortified biscuits as compared to control biscuits. Nutritional content was observed to be maximum in fresh freeze dried fortified biscuits with $0.30 \mathrm{~g} / 100 \mathrm{~g}$ amino acids, $1.27 \mathrm{~g} / 100 \mathrm{~g}$ protein, $20.45 \mathrm{~g} / 100 \mathrm{~g}$ carbohydrate, $0.22 \mathrm{~g} / 100 \mathrm{~g}$ phenol, $0.18 \mathrm{~g} / 100 \mathrm{~g}$ phytosterol, $62.44 \mathrm{~g} / 100 \mathrm{~g}$ neutral detergent fiber (NDF) and $5.16 \mathrm{~g} / 100 \mathrm{~g}$ acid detergent fiber (ADF) whereas anti-nutrients content was minimum in 20 minutes boiled shoot fortified biscuits with $5.98 \mathrm{mg} / \mathrm{kg}$ amongst the fortified biscuits. Anti-nutrient content in all the fortified biscuits were much below the permissible level. Sensory analysis showed higher acceptability in 20 minute boiled fortified biscuits. Compared to the control, minerals such as $\mathrm{K}, \mathrm{P}, \mathrm{S}, \mathrm{Na}, \mathrm{Ca}, \mathrm{Zn}$, $\mathrm{Fe}, \mathrm{Mn}$, increased in fortified biscuits. Freeze-dried bamboo shoot fortified biscuits were better in nutritional quality as well as better organoleptic properties compared to the control.
\end{abstract}

Keywords: bamboo shoot, processing, freeze-dried, biscuits, nutrients, fortification
Volume 6 Issue 4 - 2018

\author{
Oinam Santosh,' Harjit Kaur Bajwa,' Madho \\ Singh Bisht, ${ }^{2}$ Chongtham Nirmala' \\ 'Department of Botany, Panjab University, Chandigarh, India \\ ${ }^{2}$ Center for Science Education, NEHU, shillong, India
}

Correspondence: Chongtham Nirmala, Department of Botany, Panjab University, Chandigarh, India, Tel 91-0I72-253402I, Email cnirmalal0@gmail.com

Received: April 25, 2018| Published: July 16, 2018

\section{Introduction}

Bamboo shoots have a long history of being used as a source of food and medicine in China and South-East Asia being considered as "King of Forest Vegetables" and a "Treasure Dish". The young shoots are not only consumed as fresh vegetable but are also processed and preserved in many forms such as dried, fermented, salted, pickled, water soaked and canned. The juvenile shoots are not only delicious but are rich in nutrients mainly proteins, carbohydrates, minerals and vitamins and low in fat and calories. The presence of bioactive compounds like phenols, phytosterols and dietary fibers with health promoting properties play a vital role in protection against oxidative stress, inflammation, diabetes, cancer, obesity and cardiovascular diseases. Moreover, the shoots are a rich source of natural antioxidants due to the presence of phenols, vitamin C \& E and mineral elements such as selenium, copper, zinc, iron and manganese and have huge potential in the food and pharmaceutical industry. ${ }^{1}$ Due to their health enhancing properties, bamboo shoots are now being considered as a health food or natural functional food. ${ }^{2,3}$ However, bamboo shoots sprout only during the monsoon season due to which they have to be harvested and processed within a very short period for use round the year. Moreover, the shoots contain an anti-nutrient cyanogenic glucoside which needs to be removed for safe consumption.

Bamboo mainly grows in tropical and subtropical parts of the world like South-East Asia, South America and some parts of Africa but major demand for bamboo shoots is from developed countries like United States, Canada, Europe and Australia which requires proper processed and well-packed shoots for long distance transportation and increase in shelf life., ${ }^{4,5}$ Novel processing techniques are required in order to meet the demand for shoots for food fortification and developing nutraceuticals. Among the different processing techniques, drying and dehydration is one of the most important and widely practiced technique as it is convenient for packaging, storage and transportation. ${ }^{6}$ During the last decade, novel ways of bamboo shoot consumption have developed that require bamboo shoots in various usable forms. Converting of bamboo shoots into powder for food fortification is one very popular and convenient processing method which is being used worldwide. ${ }^{7,8}$ The present study was carried out to study nutritional content and organoleptic qualities from freeze dried powder fortified biscuits from fresh, 20minutes boiled and 24hours plain water soaked shoots of bamboo. As far as per our knowledge, this is the first report of usage of bamboo shoot freeze dried powder for food fortification.

\section{Materials and methods}

\section{Procurement of plant material}

Young shoots of Dendrocalamus hamiltonii Nees \& Arn. ex Munro was collected from the local vegetable market of Shillong, Meghalaya (India), during the months of June to September and transported to Chandigarh for further experiments. Outer culm sheath was peeled and damaged parts removed and edible part of the shoot was washed properly. 


\section{Preparation of bamboo shoot powder}

Small chunks of bamboo shoots were divided into three parts; fresh, 20minutes boiled and 24hours plain water soaked. Shoots were separately freeze-dried in vacuum fridge (Skadi, Europe) at $-50^{\circ} \mathrm{C}$ for 24hours. The freeze-dried shoots were powdered using a grinder, sieved and put in air tight glass bottles and stored at $4^{\circ} \mathrm{C}$ for further analysis.

\section{Preparation of bamboo shoot biscuits}

Biscuits of four formulations were prepared, with wheat flour and/ or bamboo powder, sugar and butter. One formulation was kept as a control having only $100 \mathrm{~g}$ wheat flour. In the other three formulations, $10 \%$ of the wheat flour was replaced with bamboo shoot powder of fresh freeze-dried, 20minutes boiled freeze dried and 24hours soaked freeze dried. The other ingredients used for all formulations were as follows: ghee or clarified butter $(30 \mathrm{~g})$, sugar $(40 \mathrm{~g})$, milk $(60 \mathrm{ml})$ and baking powder $(2 \mathrm{~g})$. All the ingredients were mixed separately for each formulation to make the dough. Uniform biscuits of thickness $3 \mathrm{~mm}$ and a circular $2.5 \mathrm{~cm}$ diameter were prepared using a wooden rolling pin and baked at $200^{\circ} \mathrm{C}$ for $15-20 \mathrm{~min}$. Biscuits were cooled at room temperature and placed in an airtight glass bottle for further analysis.

\section{Nutritional and sensory analysis}

Nutritional analysis for freeze-dried bamboo shoot powder and products (biscuits) was performed for nutrients and bioactive compounds using the established methods for total carbohydrate content, ${ }^{9}$ free amino acids, ${ }^{10}$ starch content, ${ }^{11}$ total proteins, ${ }^{12}$ vitamin $\mathrm{C},{ }^{13}$ Vitamin E, ${ }^{14}$ dietary fiber estimation after extraction of fat and sugar from sample, ${ }^{15,16}$ total phenols using Folin-Ciocalteau method, ${ }^{17}$ and total phytosterols, ${ }^{18}$ ash content, ${ }^{19}$ and crude fat. ${ }^{20}$ Mineral content was estimated using wavelength dispersive $\mathrm{x}$-ray fluorescence spectroscopy (WDXRF). For mineral analysis of the products (biscuits), samples were homogenized to a fine powder with mortar pestle and spread over tissue paper at room temperature for 24hours for air drying and removal of excess fat content after which mineral analysis was carried out.

\section{Statistical analysis}

The analysis was performed in triplicate and data were reported as mean \pm SD. One-way analysis of variance (ANOVA) using PASW Statistics (version 18.0.0) determine the level of significance by Duncan test. In case of sensory analysis, data $(n=20)$ were analyzed using Tukey test to separate the means of other parameters that examined the acceptability of the biscuits. The numerical consequence was well-defined at $\mathrm{P} \leq 0.05$.

\section{Result and discussion}

\section{Anti-nutrients in freeze-dried bamboo shoot powder and fortified biscuits}

A major deterrent in the consumption of bamboo shoot is the acridity and peculiar smell which is due to the presence of the antinutrient cyanogenic glucoside which has been reported from many bamboo species. ${ }^{21,22,23}$ If not removed properly, cyanogenic glucosides are toxic to humans. Cyanogenic glycoside reacts with glycosidase and releases hydrocyanic acid (Prussic acid, or cyanide) which is harmful for consumption. ${ }^{24}$ Cyanogenic glycoside content in freezedried shoot powder of $D$. hamiltonii ranged from $3692 \mathrm{mg} / \mathrm{kg}$ in fresh shoots to $1152 \mathrm{mg} / \mathrm{kg}$ in 24 hours water soaked shoots and $219 \mathrm{mg} / \mathrm{kg}$ in 20minutes boiled shoots (Table 1). It has been reported that these anti-nutrients can easily be removed by washing, soaking, drying and fermentation of shoots. ${ }^{22,24,25}$ The cyanogenic glycoside content from a very high level of $3692 \mathrm{mg} / \mathrm{kg}$ in the fresh freeze-dried powder reduced to $219 \mathrm{mg} / \mathrm{kg}$, below the permissible limit after boiling 20minutes (Tables 1). However, soaking of shoots for 24hours was not so efficient method for removing the cyanogenic glycoside. The freeze-dried powder from 24 hours water soaked shoots was around $1152 \mathrm{mg} / \mathrm{kg}$, more than double of the permissible limit. ${ }^{22}$ However, it was interesting to observe that the cyanogenic glycoside level in the fortified biscuits with freeze-dried powder dropped down to negligible level after baking at $200^{\circ} \mathrm{C}$ temperature. Cyanogenic glycoside content of the biscuits prepared with freeze-dried powder of 20 minutes boiled shoots was $5.98 \mathrm{mg} / \mathrm{kg}$ followed by $11.79 \mathrm{mg} / \mathrm{kg}$ and $18.83 \mathrm{mg} / \mathrm{kg}$ in biscuits prepared from a freeze-dried powder of 24 hours water soaked and fresh shoot, respectively (Table 4). Whereas in the freeze-dried powder of fresh and 24hours soaked shoots, the cyanogenic content was high and beyond the permissible limit of $500 \mathrm{mg} / \mathrm{kg}$ dry weight (Table 1). ${ }^{26}$

\section{Nutrients, bioactive compounds and minerals in bamboo shoot freeze-dried powder and wheat flour}

Nutrients, bioactive compounds, dietary fibers and mineral elements were analyzed in the freeze-dried bamboo shoot powder as well as in the wheat flour before mixing them together for making biscuits (Table 1-3). It was observed that freeze-dried bamboo powder was very rich in free amino acids, protein, carbohydrates, ash and fat compared to wheat flour (Table 1). Amino acids, protein, carbohydrate and fat in freeze-dried powder from fresh shoots were $24.22 \mathrm{~g} / 100 \mathrm{~g}, 36.03 \mathrm{~g} / 100 \mathrm{~g}, 21.47 \mathrm{~g} / 100 \mathrm{~g}$, and $13.27 \mathrm{~g} / 100 \mathrm{~g}$ of bamboo shoot, respectively (Table 1). Whereas, in the amino acids, protein, carbohydrate, and fats content were very low, $0.21 \mathrm{~g} / 100 \mathrm{~g}, 9.61 \mathrm{~g} / 100 \mathrm{~g}$, $0.65 \mathrm{~g} / 100 \mathrm{~g}$ and $1.75 \mathrm{~g} / 100 \mathrm{~g}$ in wheat flour, respectively (Table 1 ). Among the three samples of bamboo shoots, powder from fresh shoots was the richest in amino acids, protein, carbohydrates and fats followed by 24 hours plain water soaked and then the 20 minutes boiled shoots (Table 1). Fat content in bamboo shoot freeze-dried powder did not show much effect on processing of shoots for 20minutes boiling and 24 hours water soaking compared to fresh freeze-dried powder (Table 1).

Table I Nutritional content $(\mathrm{g} / \mathrm{/00 \textrm {g }}$ dry weight), vitamin C and $\mathrm{E}(\mathrm{mg} / \mathrm{l} 00 \mathrm{~g}$ dry weight), cyanogenic glycoside ( $\mathrm{mg} / \mathrm{kg}$ dry weight) in wheat flour and freeze-dried bamboo shoot powder

\begin{tabular}{lllll}
\hline \multirow{2}{*}{ Parameter } & $\begin{array}{l}\text { Wheat } \\
\text { Flour }\end{array}$ & \multicolumn{3}{l}{ Freeze-dried bamboo shoot powder } \\
\cline { 3 - 5 } & fresh & $\begin{array}{l}\text { 20 minutes } \\
\text { boiled }\end{array}$ & $\begin{array}{l}\text { 24 hours } \\
\text { soaked }\end{array}$ \\
\hline Amino acid & $0.21 \pm 0.0 I^{\mathrm{d}}$ & $24.22 \pm 0.66^{\mathrm{a}}$ & $15.34 \pm 0.66^{\mathrm{c}}$ & $21.96 \pm 0.75^{\mathrm{b}}$ \\
Proteins & $9.61 \pm 0.20^{\mathrm{d}}$ & $36.03 \pm 0.2 \mathrm{I}^{\mathrm{a}}$ & $10.68 \pm 0.63^{\mathrm{c}}$ & $19.12 \pm 0.41^{\mathrm{b}}$ \\
Carbohydrates & $0.65 \pm 0.0 \mathrm{I}^{\mathrm{d}}$ & $21.47 \pm 0.72^{\mathrm{a}}$ & $15.34 \pm 0.20^{\mathrm{b}}$ & $12.74 \pm 0.65^{\mathrm{c}}$ \\
Starch & $76.51 \pm 1.59^{\mathrm{a}}$ & $6.11 \pm 0.04^{\mathrm{b}}$ & $6.48 \pm 0.04^{\mathrm{b}}$ & $5.10 \pm 0.05^{\mathrm{b}}$ \\
Fat & $1.75 \pm 0.12^{\mathrm{c}}$ & $13.27 \pm 0.93^{\mathrm{a}}$ & $12.33 \pm 0.5 \mathrm{I}^{\mathrm{ab}}$ & $13.90 \pm 0.46^{\mathrm{a}}$ \\
Vitamin C & $0.63 \pm 0.05^{\mathrm{d}}$ & $17.48 \pm 0.12^{\mathrm{a}}$ & $13.09 \pm 0.79^{\mathrm{b}}$ & $12.11 \pm 0.23^{\mathrm{c}}$ \\
Vitamin E & $0.54 \pm 0.02^{\mathrm{c}}$ & $5.44 \pm 0.28^{\mathrm{a}}$ & $4.94 \pm 0.22^{\mathrm{b}}$ & $4.75 \pm 0.11^{\mathrm{b}}$ \\
Cyanogenic & $0.00 \pm 0.00^{\mathrm{d}}$ & $3692.48 \pm 21.43^{\mathrm{a}}$ & $219.65 \pm 4.84^{\mathrm{c}}$ & $1152 \pm 18.36^{\mathrm{b}}$ \\
glycoside & & & &
\end{tabular}

Values reported are measurement replication means \pm standard deviation $(n=03$ replicates). Mean followed by different letters in the same row differs significantly $(\mathrm{P} \leq 0.05)$. 
A similar trend was also observed in the bioactive compounds phenols, phytosterols and vitamin C \& E. Wheat flour was very poor in these bioactive compounds compared to the bamboo shoot powder. Processing also reduced the amount of phenols and phytosterols in freeze-dried powder in 20minutes boiled and 24hours water soaked bamboo shoots, but the amount of Vitamin $\mathrm{C}$ and $\mathrm{E}$ was not much affected by processing (Table 1 ).

In dietary fiber content, NDF (Neutral Detergent Fiber), ADF (Acid Detergent Fibers), lignin, cellulose and hemicellulose were much more in freeze-dried bamboo shoot powder compared to wheat flour (Table 3). Among the processed forms hemicellulose was more in the powder from fresh freeze-dried shoots but in 20 minutes boiled and the 24 hours soaked freeze-dried powder were lower as compared to wheat flour (Table 3).

Bamboo shoot powder is richer in the minerals $\mathrm{K}, \mathrm{Cl}, \mathrm{P}, \mathrm{Ca}, \mathrm{S}$, $\mathrm{Mg}, \mathrm{Si}$ and $\mathrm{Na}$ compared to the wheat flour (Table 2). Potassium, the heart-protecting mineral was more than $4000 \mathrm{mg} / 100 \mathrm{~g}$ in bamboo shoot powder, whereas in wheat flour it was just $163 \mathrm{mg} / 100 \mathrm{~g}$ (Table 2). Similarly, other important minerals like phosphorus, calcium, magnesium and silica were also high in freeze-dried bamboo shoot powder than the wheat flour (Table 2). Processing of bamboo shoots (20minutes boiling and soaking in water for 24hours) reduced the amount of minerals to some level in the freeze-dried powder (Table 2). Some minerals like $\mathrm{K}, \mathrm{P}, \mathrm{Fe}, \mathrm{Br}$, and $\mathrm{Mn}$ were reduced maximum in freeze-dried powder from 24 hours soaked shoots, whereas minerals like $\mathrm{K}, \mathrm{Cl}, \mathrm{Si}, \mathrm{Cu}$ and $\mathrm{Ni}$ were reduced more by boiling shoots for 20 minutes (Table 2). Bamboo shoot freeze-dried powder from fresh, 20 minutes boiled or 24 hours soaked was also rich in micro-minerals like zinc, iron and copper than the wheat flour (Table 2).

\section{Bamboo shoot powder fortified biscuits}

Bamboo shoots in different forms, whole, small pieces, chunks, strips, paste or powder are now being used for making various recipes and fortified food items. ${ }^{3,27,28,29}$ However, for the first time, freezedried powder from fresh, 20minutes boiled, 24hours water soaked bamboo shoots were used for the fortification of food products. Processing (20minutes boiling and 24hours soaking) of bamboo shoots for removal of anti-nutrients like cyanogenic glycosides are important aspects in bamboo shoot consumption. ${ }^{30,31}$

\section{Nutritional properties of fortified biscuits with bamboo shoot powder}

Biscuits fortified with freeze-dried bamboo shoot were analyzed for nutrients, bioactive compounds, minerals and vitamins. Freeze dried powder from fresh, 20minutes boiled and 24hours soaked shoots gave different results in the enrichment of fortified biscuits.

Nutrients: It was observed that bamboo shoot powder fortified biscuits were highly enriched with nutrients like protein, carbohydrates, starch, fat, ash and amino acids compared to the control biscuits without bamboo shoot powder. Control biscuits showed amino acid content around $0.06 \mathrm{~g} / 100 \mathrm{~g}$ which increased in bamboo shoot fortified biscuits above $0.19 \mathrm{~g} / 100 \mathrm{~g}$ (Table 4$)$. The maximum increment in amino acid content was observed in the biscuits fortified with freeze-dried powder from fresh bamboo shoots. All other nutrient elements like proteins, carbohydrates, starch, ash and fats also showed increments in the fortified biscuits (Table 4). Protein and carbohydrates showed very high level of increment. The protein content in control biscuits was around $0.40 \mathrm{~g} / 100 \mathrm{~g}$ which increased to $1.27 \mathrm{~g} / 100 \mathrm{~g}$ in bamboo shoot fortified biscuits (Table 4). Similarly, the increment in carbohydrate level in bamboo shoot fortified biscuits was 65 percent to 123 percent (Table 4). Starch content also increased in the bamboo shoot fortified biscuits, but not to the extent as of amino acids, proteins and carbohydrates (Table 4). In fortified biscuits, starch content increased from 19.56 to 31.21 percent (Table 4).

Bio-active compounds: Increment in the level of phenols, phytosterols, vitamin $\mathrm{C}$ and $\mathrm{E}$ were also analyzed in freeze-dried bamboo shoot fortified biscuits. The increase in phenol levels was very high ranging from 100 to 120percent (Table 5). Fresh bamboo shoot powder fortified biscuits had more content of phenols (Table 5 ). This may be because of higher phenolic content in the powder obtained from the fresh shoots (Table 3 ). Fortified biscuits also showed an increase in the phytosterol content but not that much as observed in case of phenols. Phytosterol increased to a maximum level of 12.5percent in biscuits fortified with powder from fresh shoots (Table 5). Vitamin contents (C and E) also showed appreciable increment in fortified biscuits. In control biscuits, the Vitamin $\mathrm{C}$ content was $1.03 \mathrm{mg} / 100 \mathrm{~g}$ which increased in fortified biscuits at $2.20 \mathrm{mg} / 100 \mathrm{~g}$ (up to 113.59 percent) due to the addition of freeze-dried bamboo shoot powder (Table 4). A similar increase of up to 52percent was also observed in the content of vitamin E (Table 4).

Dietary fiber: Dietary fiber which is also called roughage is a very important component of diet and for overall health and the recommended level of it is 25 to $30 \mathrm{~g}$ a day in combination with at least 2 liters of water for thorough digestion. ${ }^{3}$ Dietary fiber includes cellulose, lignin, hemicelluloses, pectins, gums, many other polysaccharides and oligosaccharides..$^{32}$ Bamboo shoots are known for rich and cheap source of dietary fiber ranging from 2.23 to $4.20 \mathrm{~g}$ fresh weight of shoot in some bamboo species. ${ }^{3,33}$ In bamboo shoot fortified biscuits, the dietary fiber component showed increment, maximum being in biscuits added with freeze-dried powder from fresh shoots (Table 5). The maximum increment was observed in case of lignin. This lignin in biscuits is from the bamboo shoot powder as the wheat flour in pure form is having very less lignin content (Table 5). Similarly, the level of hemicelluloses also increased quite appreciably in fortified biscuits.

\section{Organoleptic characters}

In general, sensory observations like smell, taste, appearance are the traits which influence the food acceptance more than the nutritive value. Characters like appearance, smell and taste play a significant role in the selection of a food item. Some bamboo shoots, particularly from $D$. hamiltonii, are not accepted by the people in raw form for food due to the pungent smell and bitter taste. Post-harvest processing of shoots is very essential in these species of bamboos to make them palatable. In the present study, bamboo shoots were processed at two levels to remove the acrid smell and bitter taste from the product fortified with bamboo shoot powder. Shoots were boiled for 20 minutes and soaked for 24 hours and then freeze-dried. Regarding the color, the fortified biscuits from fresh shoots have the highest score of 6.20 followed by biscuits fortified from freeze-dried powder for 20 minutes boiled shoots (Table 6). For other characters like aroma, texture, taste and overall characteristics, biscuits fortified with freeze-dried powder from 20minutes boiled shoots were above 6.0 on the hedonic scale (Table 6). It was seen that boiling for at least 20 minutes of bamboo shoots is essential to remove the acridity and bitterness from shoots and make them acceptable to the people who were totally new to the taste of bamboo shoots. The sensory results would be different from the people who are habitual of consuming bamboo shoots, like people of North-East India who regularly eat bamboo shoots. 


\section{Mineral elements}

Bamboo shoot is a good source of minerals such as $\mathrm{K}, \mathrm{P}, \mathrm{Na}, \mathrm{Mg}$, $\mathrm{Ca}$, and $\mathrm{Fe}$ and it also contains trace elements such as cadmium, cobalt, copper, nickel, manganese, selenium, and zinc.,34 In the present study, among the three different forms of fortified biscuits, 20minutes boiled freeze dried bamboo shoot powder fortified biscuits show the higher sensory score. Comparing the nutrients, biscuits fortified with fresh freeze-dried powder was higher but the sensory acceptability is very low. Considering the overall nutrient, bioactive compounds and sensory attributes, mineral analysis was carried out for biscuits fortified with 20minutes boiled freeze dried bamboo shoot powder and control biscuits. It was observed that macro elements $\mathrm{K}, \mathrm{P}, \mathrm{S}$, $\mathrm{Na}, \mathrm{Cl}, \mathrm{Mg}, \mathrm{Ca}, \mathrm{Si}$ content increased in fortified biscuits. Similarly, micro elements such as $\mathrm{Zn}, \mathrm{Fe}, \mathrm{Mn}, \mathrm{Ni}$, and $\mathrm{Cr}$ were more in biscuits fortified with 20 minutes boiled freeze-dried powder. Potassium, a heart-friendly mineral increased about $131 \%$ with the fortification of bamboo shoot (Table 7). Iron content increased from $2.9 \mathrm{mg} / 100 \mathrm{~g}$ of control biscuits to $4.5 \mathrm{mg} / 100 \mathrm{~g}$ in fortified biscuits. Iron deficiency is very prevalent in many parts of the world, particularly in developing countries like India ${ }^{35}$ and fortification of common and popular food items like biscuits with bamboo shoots can increase the iron content. Zinc is another micro mineral element and its deficiency may lead to retarded skeletal development and immunodeficiency disorders. In bamboo shoot fortified biscuits, the increment of zinc was around $27.27 \%$ (Table 7). Micronutrient deficiency is the source of hidden hunger in the world today affecting over two billion people worldwide. ${ }^{36}$ A way to address such deficiencies cheaply is through food fortification or supplementation and bamboo shoots which is rich in minerals and vitamins is a potential source.

Table 2 Comparative account of various mineral elements present in the freeze-dried shoots of $D$. hamiltonii (mg/ $/ 00 \mathrm{~g}$ dry weight) and wheat flour

\begin{tabular}{|c|c|c|c|c|}
\hline \multirow{2}{*}{ Parameter } & \multirow{2}{*}{ Wheat Flour } & \multicolumn{3}{|c|}{ Freeze-dried bamboo shoot powder } \\
\hline & & fresh & 20 minutes boiled & 24 hours soaked \\
\hline \multicolumn{5}{|c|}{ Macro-elements } \\
\hline K & $|63.67 \pm 3.5|^{d}$ & $4910.00 \pm 30.00^{\mathrm{a}}$ & $4360.00 \pm 10.00^{c}$ & $4513.67 \pm 32.72^{b}$ \\
\hline $\mathrm{Cl}$ & $60.00 \pm 2.00^{d}$ & $860.00 \pm 10.00^{\mathrm{a}}$ & $616.67 \pm 4.93^{c}$ & $845.00 \pm 5.00^{\mathrm{b}}$ \\
\hline$P$ & $150.67 \pm 7.02^{\mathrm{d}}$ & $507.67 \pm 6.81^{\mathrm{b}}$ & $520.33 \pm 1.53^{\mathrm{a}}$ & $488.00 \pm 2.65^{c}$ \\
\hline $\mathrm{Ca}$ & $29.67 \pm 1.53^{\mathrm{d}}$ & $|16.33 \pm 5.5|^{c}$ & $277.67 \pm 4.93^{\mathrm{a}}$ & $237.67 \pm 4.93^{\mathrm{b}}$ \\
\hline$S$ & $128.67 \pm 1.53^{c}$ & $239.67 \pm 5.5 I^{b}$ & $288.00 \pm 2.65^{a}$ & $288.00 \pm 2.65^{\mathrm{a}}$ \\
\hline $\mathrm{Mg}$ & $50.00 \pm 2.00^{c}$ & $169.00 \pm 3.6 \mathrm{I}^{\mathrm{b}}$ & $181.33 \pm\left. 3.2\right|^{\mathrm{a}}$ & $169.00 \pm 3.61^{b}$ \\
\hline $\mathrm{Si}$ & $27.33 \pm 2.08^{\mathrm{d}}$ & $189.00 \pm 3.6 \mathrm{I}^{\mathrm{a}}$ & $127.67 \pm 2.52^{c}$ & $179.00 \pm 3.6 \mathrm{I}^{\mathrm{b}}$ \\
\hline $\mathrm{Rb}$ & - & $21.33 \pm 1.53^{b}$ & $32.67 \pm 3.06^{\mathrm{a}}$ & $21.33 \pm 1.53^{b}$ \\
\hline $\mathrm{Na}$ & - & $11.00 \pm 1.00^{\mathrm{a}}$ & $11.00 \pm 1.00^{\mathrm{a}}$ & $11.00 \pm 1.00^{\mathrm{a}}$ \\
\hline \multicolumn{5}{|c|}{ Micro-elements } \\
\hline $\mathrm{Zn}$ & $1.33 \pm 0.15^{d}$ & $8.20 \pm 0.10^{c}$ & $9.60 \pm 0.36^{a}$ & $8.60 \pm 0.10^{b}$ \\
\hline $\mathrm{Fe}$ & $2.33 \pm 0.2 \mathrm{I}^{\mathrm{d}}$ & $8.47 \pm 0.15^{a}$ & $7.37 \pm 0.38^{\mathrm{b}}$ & $6.67 \pm 0.21^{c}$ \\
\hline Mn & - & $2.20 \pm 0.26^{b}$ & $1.03 \pm 0.15^{c}$ & $6.47 \pm 0.3 \mathrm{I}^{\mathrm{a}}$ \\
\hline $\mathrm{Br}$ & - & $1.94 \pm 0.04^{b}$ & $2.89 \pm 0.09^{a}$ & $1.79 \pm 0.10^{c}$ \\
\hline $\mathrm{Cu}$ & $0.83 \pm 0.04^{c}$ & $2.68 \pm 0.1 \mathrm{I}^{\mathrm{a}}$ & $2.25 \pm 0.05^{b}$ & $2.63 \pm 0.04^{a}$ \\
\hline $\mathrm{Ru}$ & $2.27 \pm 0.15^{\mathrm{a}}$ & $1.73 \pm 0.05^{b}$ & $1.83 \pm 0.05^{b}$ & $1.40 \pm 0.02^{c}$ \\
\hline $\mathrm{Ni}$ & $0.50 \pm 0.10^{c}$ & $1.53 \pm 0.35^{\mathrm{ab}}$ & $1.23 \pm 0.15^{b}$ & $1.80 \pm 0.10^{a}$ \\
\hline $\mathrm{Sr}$ & - & $0.73 \pm 0.05^{\mathrm{a}}$ & $0.73 \pm 0.05^{a}$ & $0.73 \pm 0.05^{a}$ \\
\hline
\end{tabular}

Values reported are measurement replication means \pm standard deviation ( $\mathrm{n}=03$ replicates). Mean followed by different letters in the same row differs significantly $(\mathrm{P} \leq 0.05)$. 
Freeze-dried bamboo shoot powder for food fortification: enrichment of nutritional content and

Table 3 Phenol, phytosterol and dietary fiber content (g/I00g dry weight) in wheat flour and freeze-dried bamboo shoot powder

\begin{tabular}{|c|c|c|c|c|}
\hline \multirow{2}{*}{ Parameter } & \multirow{2}{*}{ Wheat Flour } & \multicolumn{3}{|c|}{ Freeze-dried bamboo shoot powder } \\
\hline & & fresh & 20 minutes boiled & 24 hours soaked \\
\hline \multicolumn{5}{|c|}{ Bioactive compounds } \\
\hline Phenol & $0.39 \pm 0.0 \mathrm{I}^{\mathrm{d}}$ & $5.45 \pm 0.12^{b}$ & $2.81 \pm 0.16^{c}$ & $5.00 \pm 0.02^{\mathrm{b}}$ \\
\hline Phytosterol & $0.14 \pm\left. 0.0\right|^{d}$ & $0.32 \pm 0.0 \mathrm{I}^{\mathrm{a}}$ & $0.30 \pm 0.0 \mathrm{I}^{\mathrm{b}}$ & $0.24 \pm 0.0 \mathrm{I}^{\mathrm{c}}$ \\
\hline \multicolumn{5}{|l|}{ Dietary fiber } \\
\hline NDF & $53.43 \pm 0.04^{b}$ & $64.12 \pm 0.03^{\mathrm{a}}$ & $57.16 \pm 0.0 I^{b}$ & $54.40 \pm 0.04^{b}$ \\
\hline ADF & $0.46 \pm 0.0 \mathrm{I}^{\mathrm{c}}$ & $|4.8| \pm\left. 0.0\right|^{\mathrm{a}}$ & $12.42 \pm 0.01^{b}$ & $\mathrm{II} .58 \pm 0.0 \mathrm{I}^{\mathrm{b}}$ \\
\hline Lignin & $0.42 \pm 0.0 \mathrm{I}^{\mathrm{c}}$ & $5.50 \pm 0.0 \mathrm{I}^{\mathrm{a}}$ & $4.48 \pm 0.0 \mathrm{I}^{\mathrm{b}}$ & $4.12 \pm 0.0 \mathrm{I}^{\mathrm{b}}$ \\
\hline Cellulose & $0.04 \pm 0.0 \mathrm{I}^{\mathrm{c}}$ & $9.31 \pm 0.0 \mathrm{I}^{\mathrm{a}}$ & $7.94 \pm 0.0 \mathrm{I}^{\mathrm{a}}$ & $4.14 \pm 0.04^{b}$ \\
\hline Hemicellulose & $52.97 \pm 0.04^{a}$ & $53.78 \pm 0.03^{\mathrm{a}}$ & $44.74 \pm 0.0 \mathrm{I}^{\mathrm{b}}$ & $42.82 \pm 0.03^{b}$ \\
\hline
\end{tabular}

Values reported are measurement replication means \pm standard deviation ( $\mathrm{n}=03$ replicates). Mean followed by different letters in the same row differs significantly $(\mathrm{P} \leq 0.05)$.

Table 4 Nutritional content ( $\mathrm{g} / \mathrm{l00g}$ dry weight), vitamins ( $\mathrm{mg} / \mathrm{l00g}$ dry weight), cyanogenic glycoside ( $\mathrm{mg} / \mathrm{kg}$ dry weight) in freeze-dried bamboo shoots powder fortified biscuits and control biscuits

\begin{tabular}{|c|c|c|c|c|}
\hline \multirow{2}{*}{ Parameter } & \multirow{2}{*}{ Control biscuits } & \multicolumn{3}{|c|}{ Biscuits fortified with freeze-dried powder of } \\
\hline & & Fresh & 20 minutes boiled & 24 hours soaked \\
\hline Amino acid & $0.06 \pm 0.0 \mathrm{I}^{\mathrm{d}}$ & $0.30 \pm 0.0 \mathrm{I}^{\mathrm{a}}$ & $0.19 \pm 0.03^{c}$ & $0.26 \pm 0.0 \mathrm{I}^{\mathrm{b}}$ \\
\hline Proteins & $0.40 \pm 0.07^{d}$ & $1.27 \pm 0.05^{\mathrm{a}}$ & $1.00 \pm 0.04^{c}$ & $\mathrm{I} . \mathrm{II} \pm 0.0 \mathrm{I}^{\mathrm{b}}$ \\
\hline Carbohydrates & $9.16 \pm 0.43^{c}$ & $20.45 \pm 0.66^{a}$ & $15.16 \pm 0.46^{b}$ & $19.95 \pm 0.52^{\mathrm{a}}$ \\
\hline Starch & $57.05 \pm 0.63^{d}$ & $73.03 \pm 0.65^{b}$ & $74.86 \pm 0.08^{\mathrm{a}}$ & $68.21 \pm 0.66^{c}$ \\
\hline Fat & $26.23 \pm 0.49^{\mathrm{a}}$ & $23.03 \pm 0.70^{\mathrm{b}}$ & $23.40 \pm 0.44^{b}$ & $23.33 \pm 0.42^{b}$ \\
\hline Vitamin C & $1.03 \pm 0.0 \mathrm{I}^{\mathrm{d}}$ & $2.20 \pm 0.09^{a}$ & $1.79 \pm 0.16^{b}$ & $1.28 \pm 0.10^{c}$ \\
\hline Vitamin E & $0.39 \pm 0.05^{c}$ & $0.59 \pm 0.03^{a}$ & $0.53 \pm 0.03^{b}$ & $0.43 \pm 0.02^{c}$ \\
\hline Cyanogenic glycoside & $0.00 \pm 0.00^{d}$ & $\mid 8.83 \pm 0.8 \mathrm{I}^{\mathrm{a}}$ & $5.98 \pm 0.3 I^{c}$ & $\mathrm{II} .79 \pm 0.8 \mathrm{I}^{\mathrm{b}}$ \\
\hline
\end{tabular}

Values reported are measurement replication means \pm standard deviation ( $\mathrm{n}=03$ replicates). Mean followed by different letters in the same row differs significantly $(\mathrm{P} \leq 0.05)$.

Table 5 Phenol, phytosterol and dietary fiber content (g/l00g dry weight) in freeze-dried bamboo shoot powder and control biscuits

\begin{tabular}{|c|c|c|c|c|}
\hline \multirow{2}{*}{ Parameter } & \multirow{2}{*}{ Control } & \multicolumn{3}{|c|}{ Biscuits fortified with freeze-dried powder of } \\
\hline & & Fresh & 20 minutes boiled & 24 hours soaked \\
\hline \multicolumn{5}{|c|}{ Bioactive compounds } \\
\hline Phenol & $0.10 \pm 0.0 \mathrm{I}^{\mathrm{d}}$ & $0.22 \pm 0.0 \mathrm{I}^{\mathrm{a}}$ & $0.20 \pm 0.0 \mathrm{I}^{\mathrm{c}}$ & $0.2 \mathrm{I} \pm 0.0 \mathrm{I}^{\mathrm{b}}$ \\
\hline Phytosterol & $0.16 \pm 0.0 I^{c}$ & $0.18 \pm 0.01^{\mathrm{a}}$ & $0.17 \pm 0.0 \mathrm{I}^{\mathrm{ab}}$ & $0.17 \pm 0.0 \mathrm{I}^{\mathrm{b}}$ \\
\hline \multicolumn{5}{|l|}{ Dietary fiber } \\
\hline NDF & $46.15 \pm 0.23^{c}$ & $62.44 \pm 0.018^{\mathrm{a}}$ & $57.56 \pm 0.03^{\mathrm{ab}}$ & $55.26 \pm 0.02^{\mathrm{b}}$ \\
\hline ADF & $1.89 \pm 0.0 \mathrm{I}^{\mathrm{c}}$ & $5.16 \pm\left. 0.0\right|^{a}$ & $3.82 \pm 0.0 \mathrm{I}^{\mathrm{b}}$ & $3.53 \pm 0.0 \mathrm{I}^{\mathrm{b}}$ \\
\hline Lignin & $0.69 \pm 0.0 \mathrm{I}^{\mathrm{b}}$ & $2.66 \pm 0.0 \mathrm{I}^{\mathrm{a}}$ & $\mathrm{I} .82 \pm 0.0 \mathrm{I}^{\mathrm{ab}}$ & $\mathrm{I} .65 \pm 0.0 \mathrm{I}^{\mathrm{ab}}$ \\
\hline Cellulose & $1.2 \mathrm{I} \pm 0.0 \mathrm{I}^{\mathrm{a}}$ & $2.50 \pm 0.0 \mathrm{I}^{\mathrm{a}}$ & $2.00 \pm 0.0 \mathrm{I}^{\mathrm{a}}$ & $\mathrm{I} .88 \pm 0.0 \mathrm{I}^{\mathrm{a}}$ \\
\hline Hemicellulose & $44.26 \pm 0.23^{c}$ & $57.88 \pm 0.02^{\mathrm{a}}$ & $53.14 \pm 0.03^{\mathrm{ab}}$ & $51.73 \pm 0.03^{b}$ \\
\hline
\end{tabular}

Values reported are measurement replication means \pm standard deviation ( $\mathrm{n}=03$ replicates). Mean followed by different letters in the same row differs significantly $(\mathrm{P} \leq 0.05)$. 
Table 6 Sensory evaluation of control biscuits and D. hamiltonii shoot fortified biscuits using 9-point Hedonic scale (I-Extremely dislike to 9- Extremely like)

\begin{tabular}{|c|c|c|c|c|}
\hline \multirow{2}{*}{ Parameter } & \multirow{2}{*}{ Control } & \multicolumn{3}{|c|}{$\begin{array}{l}\text { Biscuits fortified with freeze-dried } \\
\text { powder of }\end{array}$} \\
\hline & & Fresh & $\begin{array}{l}20 \\
\text { minutes } \\
\text { boiled }\end{array}$ & $\begin{array}{l}24 \text { hours } \\
\text { soaked }\end{array}$ \\
\hline Colour & $5.45 \pm 1.18^{d}$ & $6.20 \pm 1.40^{\mathrm{a}}$ & $5.81 \pm 1.87^{b}$ & $5.70 \pm 1.86^{c}$ \\
\hline Aroma & $6.00 \pm\left. 0.9\right|^{a}$ & $4.75 \pm 1.59^{c}$ & $6.00 \pm 1.45^{\mathrm{a}}$ & $5.75 \pm 1.44^{b}$ \\
\hline Texture & $5.55 \pm 1.73^{b}$ & $5.65 \pm 1.42^{b}$ & $6.11 \pm 1.57^{a}$ & $5.15 \pm 1.56^{c}$ \\
\hline Taste & $5.90 \pm 1.99^{b}$ & $4.40 \pm 1.64^{d}$ & $6.29 \pm 1.45^{\mathrm{a}}$ & $5.25 \pm 1.44^{c}$ \\
\hline Overall & $6.20 \pm 1.50^{b}$ & $4.80 \pm 1.6 \mathrm{I}^{\mathrm{d}}$ & $6.52 \pm 1.14^{\mathrm{a}}$ & $5.35 \pm 1.13^{c}$ \\
\hline
\end{tabular}

Values reported are measurement replication means \pm standard deviation $(n=03$ replicates). Mean followed by different letters in the same row differs significantly $(\mathrm{P} \leq 0.05)$.

Table 7 Comparative account of various mineral elements present in the 20 minutes boiled freeze-dried shoots powder fortified biscuits and control biscuits. (mg/l00g dry weight)

\begin{tabular}{|c|c|c|}
\hline Parameter & Control & $\begin{array}{l}20 \text { minutes boiled } \\
\text { freeze-dried shoot } \\
\text { powder fortified biscuits }\end{array}$ \\
\hline \multicolumn{3}{|c|}{ Macro-elements } \\
\hline K & $161.33 \pm 7.09^{\mathrm{b}}$ & $373.00 \pm 7.00^{\mathrm{a}}$ \\
\hline$P$ & $113.33 \pm 6.66^{b}$ & II $18.67 \pm 7.57^{\mathrm{a}}$ \\
\hline S & $130.67 \pm 2.08^{b}$ & $144 \pm 4.00^{\mathrm{a}}$ \\
\hline $\mathrm{Na}$ & $81.33 \pm 1.53^{b}$ & $|44.33 \pm 4.5|^{\mathrm{a}}$ \\
\hline $\mathrm{Cl}$ & $72.00 \pm 4.36^{\mathrm{b}}$ & $206.00 \pm 5.29^{a}$ \\
\hline $\mathrm{Mg}$ & $30.00 \pm 1.00^{\mathrm{b}}$ & $32.67 \pm 2.52^{\mathrm{a}}$ \\
\hline $\mathrm{Ca}$ & $40.00 \pm 2.00^{b}$ & $66.33 \pm 5.69^{a}$ \\
\hline $\mathrm{Si}$ & $11.33 \pm 1.53^{\mathrm{b}}$ & $32.67 \pm 2.52^{\mathrm{a}}$ \\
\hline \multicolumn{3}{|c|}{ Micro-elements } \\
\hline $\mathrm{Zn}$ & $1.27 \pm 0.2 \mathrm{I}^{\mathrm{b}}$ & $1.70 \pm 0.20^{\mathrm{a}}$ \\
\hline $\mathrm{Fe}$ & $2.57 \pm 0.3 I^{b}$ & $4.70 \pm 0.20^{\mathrm{a}}$ \\
\hline$M n$ & $0.70 \pm 0.10^{\mathrm{b}}$ & $|.57 \pm 0.3|^{a}$ \\
\hline $\mathrm{Ni}$ & $1.23 \pm 0.15^{b}$ & $1.80 \pm 0.10^{\mathrm{a}}$ \\
\hline
\end{tabular}

Values reported are measurement replication means \pm standard deviation $(n=03$ replicates). Mean followed by different letters in the same row differs significantly $(\mathrm{P} \leq 0.05)$.

\section{Conclusion}

Bamboo shoot is a good source of nutrients and health promoting bioactive compounds. Though fresh shoots have highest nutrient and moisture content, they need to be processed to remove acridity for safe human consumption. Using freeze dried powder from bamboo shoots is one of the best ways of fortifying food items like biscuits. Freeze dried powder has long shelf life, very easy and convenient for packaging and long distance transportation. Fortification is also easy, as it can be added to any food product at any time. Boiling of shoots for at least 20minutes is better for removing anti-nutrients as well as making the shoots free from acridity and bitterness.
The present study revealed that, biscuits fortified with freezedried bamboo shoot powder are enriched with nutrients, bioactive compounds and minerals. The sensory analysis of the biscuits revealed that, the overall acceptability of 20 minutes boiled freeze dried shoots fortified biscuits were higher compared to the other forms. The taste, aroma, color and overall quality of the biscuits incorporated with fresh freeze dried shoots powder were not acceptable to the panel. The results indicate that bamboo shoots needs processing and freezedried bamboo shoot powder being a rich source of nutrients, could also be utilized for the preparation of bakery products with improved nutraceutical qualities.

\section{Funding details}

The authors are grateful to the Ministry of Food Processing Industries (V45/MFPI/R\&D/2000 Vol.IV) and Department of Biotechnology, New Delhi, Govt. of India (BT/475/NE/TBP/20132), American Bamboo Society and Ned Jaquith Foundation, USA for providing financial assistance to conduct this research work.

\section{Conflicts of interest}

The author declares none.

\section{References}

1. Nirmala C, Bisht MS, Bajwa HK, et al. Bamboo: A rich source of antioxidants and its application in the Food and Pharmaceutical industry. Trends in Food Science and Technology. 2018;77:91-99.

2. Caasi Lit MT, Punzalan DBT. Bamboo Shoots as Food Sources in the Philippines: Status and Constraints in Production and Utilization. Proceedings of $10^{\text {th }}$ World Bamboo Congress. Korea 17-22, September. 2015:1-16.

3. Nirmala C, Bisht MS, Sheena H. Nutritional properties of bamboo shoots: Potential and prospects for utilization as a health food. Comprehensive Review in Food Science and Food Safety. 2011;10(3):153-169.

4. Phimmachanh S, Ying Z, Beckline M. Bamboo resources utilization: A potential source of income to support rural livelihoods. Applied Ecology and Environmental Sciences. 2015;3(6):176-183.

5. INBAR. International Network for Bamboo and Rattan. International Trade of Bamboo and Rattan; 2012.

6. Priyanka S, Ramakrishna RM, Kodandaram RD, et al. Value Addition of Banana (Musa paradisiaca): Development and Storage Evaluation using Osmo Solar Dehydration Technique. MOJ Food process Technol. 2018;6(1):00137.

7. Choudhury M, Badwaik LS, Borah PK, et al. Influence of bamboo shoot powder fortification on physico-chemical, textural and organoleptic characteristics of biscuits. Journal of Food Science and Technology. 2015;52(10):742-6748.

8. Nimisha SM, Chauhan AS, Rekha MN. Portion of Tender Bamboo Shoot (TBS) and Development of Various Candies with and without Incorporation of Ginger and Pineapple Flavours. American Journal of Nutrition and Food Science. 2015;2(1):7-15.

9. Whistler. Methods in Carbohydrate Chemistry. New York: Academic Press Inc; 1971. p. 1-6.

10. Lee YD, Takahashi T. An improved colorimetric determination of amino acids with use of ninhydrin. Annals of Biochemistry. 1966;14(1):71-77.

11. Mecreddy RM, Guggolz J, Silviera V, et al. Determination of starch and amylose in vegetables. Analytical Chemistry. 1950;22(9):1156-1158. 
12. Bradford MM. A rapid and sensitive method for the quantitation of microgram quantities of protein utilizing the principle of protein-dye binding. Analytical Biochemistry. 1976;72(1-2):248-254.

13. Riemschneider R, Abedin MZ, Mocellin RP. Qualities and stabilisierungprufung hitzekonservierter Nahrungsmittelunter verwendung von Vit C alskrikriterium-Mittel. Alimentum. 1976;15:171.

14. Baker H, Frank O, De Angelis B, et al. Plasma tocopherol in man at various time intervals after ingesting free or acetylated tocopherol. Nutrition Reports International. 1980;21:531-536.

15. AOAC. Official Methods of Analysis. 16th ed. Washington DC: Association of Official Analytical Chemists; 1995.

16. Goering HK, Van Soest PJ. Forage Fiber Analyses (apparatus, reagents, procedures and some applications). Washington DC: Agriculture Handbook; 1970. p. 1-20.

17. Singleton VL, Rossi JA. Colorimetry of total phenolics with phosphor molybdic-phospho tungstic acid reagents. American Journal of Ethnology and Viticulture. 1965;16:144-153.

18. Srivastava RC. Bamboo new raw materials for phytosterols. Current Science. 1990;59(24):1333-1334.

19. Harbers LH. Ash analysis. In: Nielsen SS, editor. Introduction to Chemical Analysis of Foods. London: Jones and Bertlett Publishers; 1994. p. 113121.

20. AOAC. Official Methods of Analysis. 15th ed. Washington DC: Association of Official Analytical Chemists; 1990.

21. Choudhury D, Sahu JK, Sharma GD. Biochemistry of bitterness in bamboo shoots. Assam University Journal of Science \& Technology: Physical Sciences and Technology. 2010;6(2):105-111.

22. Rawat K, Nirmala C, Bisht MS. Processing Techniques for Reduction of Cyanogenic Glycosides from Bamboo Shoots. In the proceedings of 10th World Bamboo Congress. Korea 17-22, September. 2015.

23. Sarangthem K, Hoikhokim. Cyanogen content in bamboo plants. Asian Journal of Bioscience. 2010;5(2):178-180.

24. Darmayanti LPT, Duwipayana AA, Putra INK, et al. Preliminary study of fermented pickle of Tabah bamboo shoot (Gigantochloani grociliata (Buese) Kurz. International Journal of Biological, Veterinary, Agricultural and Food Engineering. 2014;8(10):999-1004.
25. Sarangthem K, Singh TN. Transformation of fermented bamboo (Dendrocalamus hamiltonii) shoots into phytosterols by microorganisms. Journal of Food Science \& Technology. 2003;40(6):622 -625.

26. Katsuzaki H, Sakai K, Achiwa Y, et al. Isolation of antioxidative compounds from bamboo shoots sheath. Nippon Shokuhin Kagaku Kogaku Kaishi. 1999;46(7):491-493.

27. Choudhury D, Sahu JK, Sharma GD. Value addition to bamboo shoots: a review. Journal of Food Science and Technology. 2012;49(4): 407-414.

28. Nirmala C, Bisht MS. Bamboo:a prospective ingredient for functional food and nutraceuticals. Bamboo Journal. 2017;30:82-99.

29. Pandey AK, Ojha V, Choubey SK. Development and shelf-life evaluation of value added edible products from bamboo shoots. American Journal of Food Technology. 2012;7(6):363-371.

30. Rawat K, Sharma V, Saini N, et al. Impact of different boiling and soaking treatments on the release and retention of antinutrients and nutrients from the edible shoots of three bamboo species. American Journal of Food Science and Nutrition Research. 2016;3(3):31-41.

31. Pandey AK, Ojha V. Precooking processing of bamboo shoots for removal of anti-nutrients. Journal of Food Science and Technology. 2014;51(1):43-50.

32. Chawla R, Patil GR. Soluble dietary fiber. Comprehensive reviews in food science and food safety. 2010;9(2):178-196.

33. Nirmala C, David E, Sheena H. Bamboo shoots: A rich source of dietary fibres. In: Klein F, Moller G editors. Deitary fibres, Fruit and Vegetable Consumption and Health. USA: Nova Science Publisher; 2009. p.15-30.

34. Saini N, Rawat K, Bisht MS, et al. Qualitative and Quantitative Mineral Element Variances in Shoots of two Edible Bamboo species after Processing and Storage Evaluated by Wavelength Dispersion X-ray Fluorescence Spectrometry. International Journal of Innovative Research in Science, Engineer and Technology. 2017;6(5):8262-8270.

35. Kotecha PV. Nutritional anemia in young children with focus on Asia and India. Indian Journal of Community Medicine. 2011;36(1):8-16.

36. Abeshu MA, Geleta B. The Role of fortification and supplementation in mitigating the hidden hunger. Journal of Nutritional Science. 2016;6:459. 